\title{
Resource assessment of Sakesar Limestone as aggregate from Salt Range Pakistan based on geotechnical properties
}

\begin{abstract}
The Sakesar limestone of Eocene age from Salt Range has been studied in detailed based on geotechnical properties with emphasis on its aggregate potential. The Sakesar Limestone was selected based on its easy availability and access with basic aim focused on economic aggregate source for future if proved as good potential. The rock samples were analyzed based on standards procedures of AASHTO by adopting ASTM standards to prove its potential and recommendation. A total of four potential sites are sampled that are A total of four localities are selected for sampling that are Tobar Valley, Bestway Cement Plant Quarry and Pail-Padhrar section. The results were analyzed for suitability as Sub Base, Base Course, Surface Course and Concrete potential. The study portrays that all sample of Sakesar limestone fall in the permissible limits of ASTM and classified as suitable aggregate for road construction work, except for Dhak Pass $(<125 \mathrm{~m})$ which are considered as weak and porous.
\end{abstract}

Keywords: limestone, aggregate, assessment, geotechnical, salt range
Volume 4 Issue I - 2020

\author{
Ehtisham UL Hassan,' Abdul Hannan, ${ }^{2}$ \\ Mehboob UR Rashid, ${ }^{3}$ Waqas Ahmed, ${ }^{4}$ \\ Muhammad Jawad Zeb, ${ }^{3}$ Sajjad Khan, ${ }^{3}$ Syed \\ Ali Abbas, ${ }^{5}$ Awais Ahmad ${ }^{3}$ \\ 'Geological Survey of Pakistan (GSP), H-8 office Islamabad, \\ Pakistan \\ ${ }^{2}$ Department of Earth Sciences, University of Sargodha, Pakistan \\ ${ }^{3}$ Geoscience Advance Research Labs, GSP Islamabad, Pakistan \\ ${ }^{4}$ National Centre of Excellence in Geology, University of \\ Peshawar, Pakistan \\ ${ }^{5}$ Geological Survey of Pakistan (GSP), Quetta, Pakistan
}

Correspondence: Mehboob UR Rashid, Geoscience Advance Research Labs, GSP Islamabad, Pakistan, Email mehboobge89@gmail.com

Received: January 29, 2020 | Published: February 12, 2020
Abbreviations: ASTM, american standards of testing materials; AASHTO, american association of state highway and transportation officials; AIV, aggregate impact value; ACV, aggregate crushing value; ST, soundness test

\section{Introduction}

Aggregate is defined as any coarse to medium grained material of origin from natural materials (igneous, Sedimentary or metamorphic rocks) or un-natural materials (geosynthetic aggregates) depending upon the source and mode of use. Aggregate is an important component of concrete by mixing an appropriate amount of cement. ${ }^{1}$ Aggregate are much important both economically, dimensional firmness and better wear resistance with quality depends upon aggregate quality. ${ }^{2}$ Aggregate occupy $70 \%$ of concrete volume, henceforth the quality of concrete (Firmness \& durability) is directly dependent upon mechanical and chemical properties of aggregates. ${ }^{3}$ The properties of aggregates that are, mineralogy, strength, hardness, specific gravity and porosity are directly inherited from parent rock from which it originated. ${ }^{4}$ The level of productivity and economic growth of developed country is dependent upon extensive used of aggregate. ${ }^{5}$ Limestone is widely used as a raw material for aggregates, attributed by factors due to it's easy availability and extensively utilization by construction and cement industries. The limestone aggregates are derived from quarrying and crushing of rocks with in potential areas of Punjab and KP. ${ }^{6-10}$

Pakistan is having a total area of $796,095 \mathrm{sq} . \mathrm{km}$ area with population greater than 200millions (Census -2017) with total road network of $228.026 \mathrm{~km}$. The construction industry are in full swing both in commercial, individual, private and government section aided by construction of roads by National Highways of Pakistan. The infrastructure activity are exerting pressure on aggregate demand, to cope with demand and supply gap new resources should be mapped and its potential is to be characterized. The current research work is focused upon resource assessment of Sakesar limestone for feasibility as aggregate based on geotechnical properties. This study will assist and new addition of potential site for resource potential which should be exploited in near future.

\section{Location and accessibility to area}

The Sakesar Limestone of Eocene age is well exposed throughout the Salt Range with potential thickness from $70 \mathrm{~m}$ to $150 \mathrm{~m}$ in Salt Range, $220 \mathrm{~m}$ in Chichali Pass and $300 \mathrm{~m}$ above in other localities of Surghar Range. ${ }^{11}$ The lithology of Sakesar Limestone is mainly limestone which is light grey to off white nodular to massive, with occasional occurrences of marls and chert. The sample are collected from four potential sites based on feasibility and good quality limestone (Figure 1).

i. Pail Padhrar (Crusher sample) Topographic sheet no 43D/6.

ii. Best way Cement factory (Quarry sample) Topographic sheet no 43D/14.

iii. Tobar valley ICI crushing plant (Crushing plant sample) Topographic sheet no 43D/14.

iv. Dhak Pass (Outcrop samples) Topographic sheet no 38P/14. 


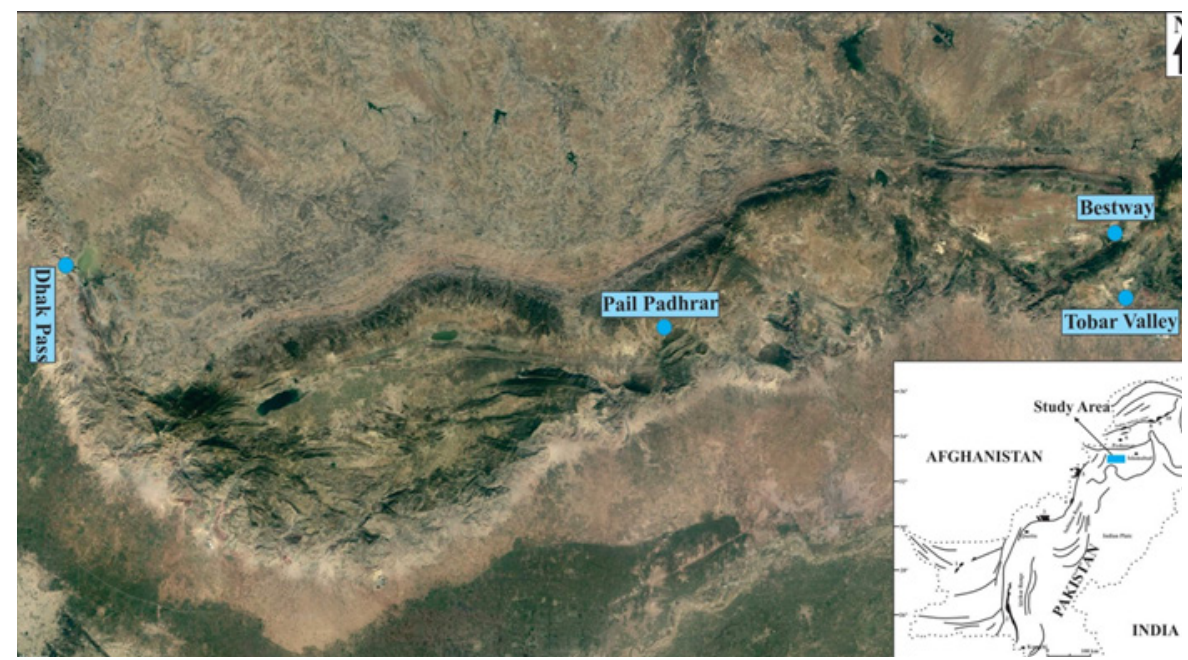

Figure I Base map of the study area showing sampling location (modified from Google map).

\section{Methodology}

\section{a. Field work}

Field work has been conducted to the study area to collect representative samples for further analysis in the labs. The samples collected are mostly in block and crushed samples by adopting ASTM D-75 ${ }^{12}$ standard depending upon the feasibility. The samples are collected from the quarry, outcrop and crushing plant.

i. Sample collected from Bestway Cement Factory cement factory Quarry working on cherty part of Sakesar Limestone at topmost 70 feet of the formation.

ii. In Pail Padhrar area, sample collected from the crushing plant working on Sakesar Limestone,

iii. Tobar valley quarry in the Eastern Salt Range working on middle part of Sakesar limestone.

iv. Sample collected from Dhak Pass at two position, basal part $(\leq 125$ meters) and topmost ( $>125$ meters) where's basal part are mostly cherty.

\section{b. Laboratory work}

The samples have been brought to the Laboratory of Uni etc.... to University of Engineering and Technology to perform different geotechnical test by adopting standard procedures of American Standards of Testing Materials (ASTM) designed by American Association of State Highway and Transportation Officials (AASHTO). The following mechanical and chemical test are performed tests were carried out on all five representative samples according to the given standards

\section{i. Mechanical test}

a. Los Angeles (LA) Abrasion Test; ${ }^{13}$

Aggregate Impact Value (AIV); ${ }^{14}$

Aggregate Crushing Value (ACV); ${ }^{15}$

b. Specific Gravity of aggregate; ${ }^{16}$

c. Water Absorption of aggregate; ${ }^{16}$

d. Unit Weight (Lose/Rodded). ${ }^{17}$ ii. Chemical test

Sodium Sulfate $\left(\mathrm{Na}_{2} \mathrm{SO}_{4}\right)$ Soundness Test. ${ }^{18}$

\section{Results}

\section{i. Los angeles (LA) abrasion value}

The LA test was performed using standard operating procedure of ASTM C-131, ${ }^{13}$ with basic aim to determine abrasion and resistance of aggregate to skidding. The analyzed sample are having abrasion values range from $\geq 21.15 \%-\leq 29.94 \%$, with higher value recorded by Dhak pass (less than 125meters) while low value shown by Pail Padhrar area (Figure 2a).

\section{ii. Aggregate impact value (AIV)}

The AIV is determined to portray the resistance of an aggregate to abrupt impact by outside forces either mechanical or applied with basic aim to determine toughness and feasibility of an aggregate to short term instantaneous applied force. The test was performed on Sakesar Limestone at five localities using British Standards BS$812 / 112 .{ }^{14}$ The AIV range from $\geq 10.09 \%-\leq 19 \%$, with high value recorded by Dhak pass (less than 125 meters) while minimum value shown by Best way cement (Figure $2 b$ ).

\section{iii. Aggregate crushing value (ACV)}

The basic principle of this test is to determine resistance of an aggregate to crushing under a gradually applied compressive load. The aim is to show the crushing ability and its resistance to crushing against traffic wheel load. The ACV directly affecting the stability of pavement, if weak aggregate with low ACV is used the pavement is readily destroyed with ease. The ACV is determined adopting British Standard procedure BS-812/110. ${ }^{15}$ The ACV values portrayed by selected samples range between $\geq 13.5 \%-\leq 25.71 \%$, with maximum value by Dhak Pass (less than 125 meters) and minimum value by Tobar Valley (Figure 2c).

\section{iv. Soundness test (ST)}

The ST is performed on representative samples of Sakesar Limestone according to standard procedure of ASTM C88-99a. ${ }^{18}$ The aim of the test is to demarcate the resistance of aggregate against weathering with focus on freeze and thaw cycle. The soundness value range from $\geq 2.63 \%-\leq 5.00 \%$, with high value shown by Dhak 
pass (less than 125meters) while low value recorded by Tobar valley (Figure 2d).

\section{v. Specific gravity and water absorption}

The specific gravity and water absorption value explains strength and quality of an aggregate, related with water retaining and percolating capacity. An aggregate having more water absorption capacity refers to be porous and prone to weathering considered as non suitable aggregate. If an aggregate have low specific gravity and more water absorption then the aggregate is considered as weaker or poor aggregate and good aggregate with vice versa properties. The water absorption and specific gravity is determined using standard procedure of ASTM 127/07. ${ }^{16}$ The results shows that Sakesar lime stone are having specific gravity range from $\geq 1.63-\leq 2.65$, with water absorption of $\geq 0.37 \%-\leq 3.1 \%$. The maximum value of $\mathrm{Sp}$.gr is shown by Bestway Cement Factory cement while low values by Dhak pass (less than 125meters), while water absorption is high for Dhak Pass (less than 125meters) and minimum for Pail Padhrar (Figures 2e\&f).

\section{vi. Unit weight of the aggregate rodded/Loose}

The aim of this test is to find unit weight of the coarse aggregate which is useful in concrete mix design and generally gave the clue that how much the aggregate is sound or porous. The test was performed at both loose and compacted (Rodded) aggregate adopting ASTM C-29 ${ }^{17}$ to portray its unit weight both loose and compacted conditions. The un compacted (Loose) unit weight ranges from $\geq 1.38 \mathrm{KN} / \mathrm{m}^{3}$ to $\leq 1.61 \mathrm{KN} /$ $\mathrm{m}^{3}$ (Figure $2 \mathrm{~g}$ ), while rodded unit value ranges from $\geq 1.46 \mathrm{KN} / \mathrm{m}^{3}$ to $\leq 1.72 \mathrm{KN} / \mathrm{m}^{3}$ with minimum value shown by Dhak pass (less than 125 meters) and maximum by Best Way cement (Figure $2 \mathrm{~h}$ ).

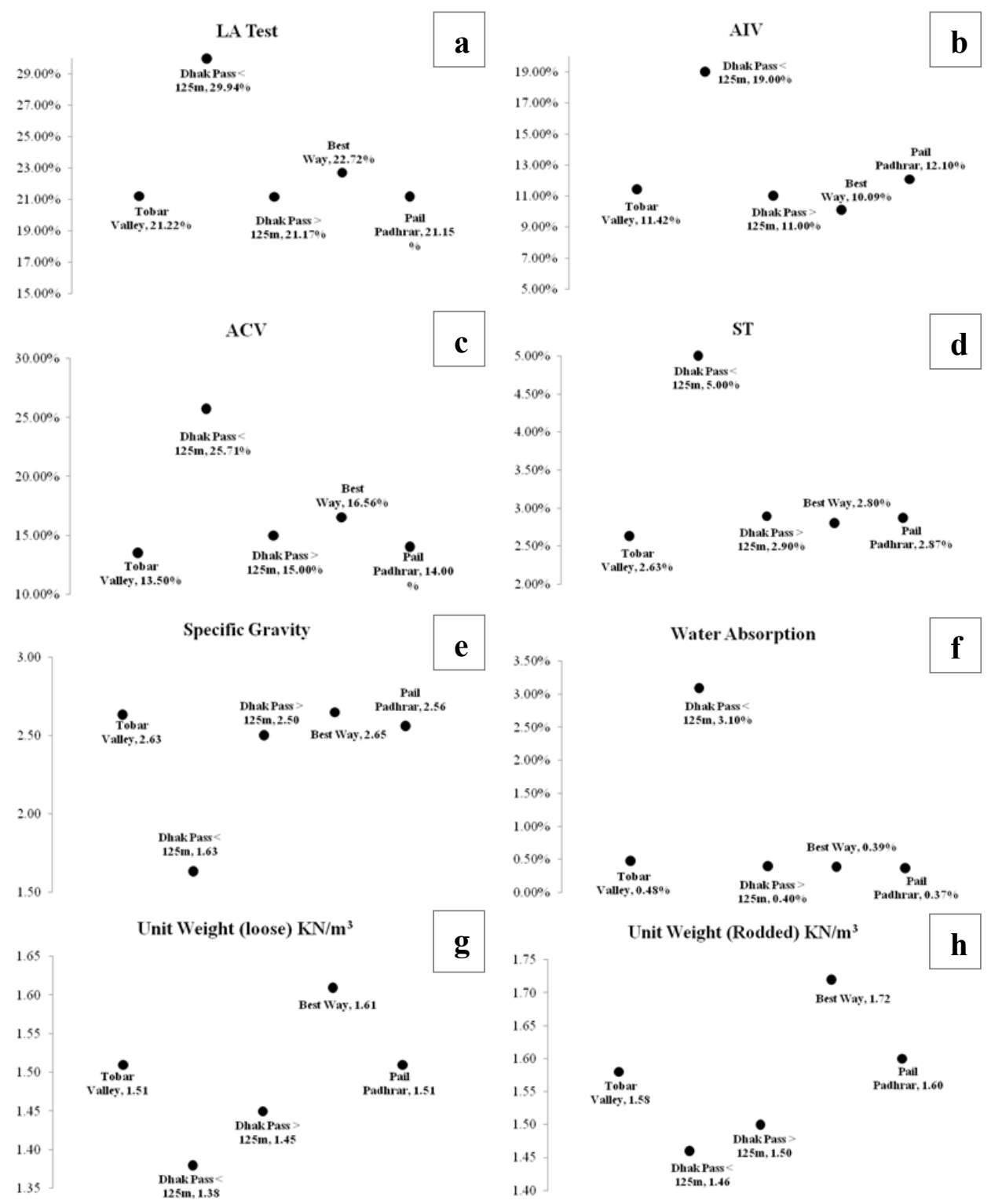

Figure 2 Assessment of Sakesar Limestone based on Geotechnical Tests, (a) Los Angeles; (LA) Abrasion Test Values; (b) Aggregate Impact Value (AIV) Test; (c) Aggregate Crushing Value (ACV) Test; (d) Soundness Test (ST) Values; (e) Specific Gravity Test Value; (f) Water Absorption Values; (g) Unit Weight (loose) Values; (h) Unit Weight (Rodded) Values. 


\section{Discussion}

The values of different tests performed on Sakesar Lime stone as an aggregate are compared with the standard value of AASHTO, ${ }^{19,20}$ and manual of Punjab Highway division standardized by Road Research and Material Testing Institute Punjab (Table 1). The standard values are adopted and compared with analyzed values for Sakesar limestone and classified as recommended for road aggregate or not.

Table I Standard base values of aggregate according to AASHTO ${ }^{19}$

\begin{tabular}{ll}
\hline Test & Base value \\
\hline LAAV & Base Course $\leq 50 \%$ \\
& Cement Concrete $\leq 16 \%$ \\
& Surface Course $\leq 30 \%$ \\
& Very Strong $<10 \%$ \\
& Very Strong $>10 \%-\leq 20 \%$ \\
AIV & Wearing Course $<30 \%$ \\
& Base Course $<45 \%$ \\
ACV & Good Aggregate $<45 \%$ \\
Water Absorption & Good aggregate $<0.6 \%$ \\
Specific Gravity & Good aggregate $\geq 2.6-\leq 2.9$ \\
Soundness Test (ST) & Max I $2 \%$ for $\mathrm{Na}_{2} \mathrm{SO}{ }_{4}$ and $18 \%$ for $\mathrm{MgSO}_{4}$ \\
\hline
\end{tabular}

The standard value for LA test for Sub Base is $50 \%$, Base course is $40 \%$ and $35 \%$ for concrete, the results obtained for LA test are $\geq 21.15 \%-\leq 29.94 \%$ which are in permissible limits of concrete (Table 2 ). All the analyzed samples of Sakesar Lime stone are recommended for use as concrete, Base course and Sub Base and Surface course (Table 3). The Pail Padhrar and Dhak Pass are having low LA value $(21.15 \% \& 21.17 \%)$ and classified as the hardest aggregate best suitable for Base course and Surface course. The standard values for AIV are classified, $<10 \%$ considered very strong, $>10-\leq 20 \%$ as strong and $>20-\leq 30 \%$ classified as suitable for road surfacing while for base course the maximum limit is $45 \%$. According to AIV of analyzed sample having range of $\geq 10.09 \%-\leq 19 \%$ which fall in the range of strong aggregate and suitable for road surfacing and Base course (Table 2). The Best Way and Dhak Pass ( $>125 \mathrm{~m})$ are designated as the hardest aggregate best suitable for Surface course in landslide prone area due to very low AIV (10.09\%\&11.00\%) (Table 3).

The ACV should have a maximum limit of $45 \%$ for Base course and $35 \%$ for Surface course, the limit of analyzed samples are $\geq 13.5 \%$ $-\leq 25.71 \%$ (Table 2). The analyzed value fall in the permissible limits except Dhak Pass $(<125 \mathrm{~m})$ which are considered as weak, based on these values Sakesar limestone is recommended for aggregate potential as Base and Surface course, sub base and concrete, with best suitable are Tobar valley and pail Padhrar (Table 3). The recommended value for Soundness Test (ST) are average weight loss on each sieve should not exceed $12 \%$ reference to ASTM standards, ${ }^{18}$ the analyzed values of Sakesar limestone range from $\geq 2.63 \%-\leq 5.00 \%$ (Table 2). The Sakesar limestone is resistance to freeze and thaw cycle of weathering as all values are less than $12 \%$, with maximum value recorded are $5 \%$ for Sakesar limestone and recommended for aggregate potential (Table 3).

The water absorption test is having values of $\geq 0.37 \%$ - $\leq 3.1 \%$ for analyzed limestone sample, the standard value should be $\leq 0.60 \%$. The lower absorption limit are shown by Pail Padhrar and Best Way $(0.37 \% \& 0.39 \%)$ and high value by Dhak Pass $(<125 \mathrm{~m})$ (Table 2$)$. Based on the result, all sample are recommend to be strong and non porous except Dhak Pass (less than 125meters) (Table 3).

Table 2 Geotechnical test results conducted on five representative samples at four potential sites of Sakesar Limestone

\begin{tabular}{|c|c|c|c|c|c|c|c|c|}
\hline & LA & AIV & ACV & ST & Sp.gr & Water Abs & $\square$ (loose) & $\square$ (rodded) \\
\hline Tobar Valley & $21.22 \%$ & $11.42 \%$ & $13.50 \%$ & $2.63 \%$ & 2.63 & $0.48 \%$ & $1.5 \mid$ & 1.58 \\
\hline $\begin{array}{l}\text { Dhak } \\
\text { Pass }<125 \mathrm{~m}\end{array}$ & $29.94 \%$ & $19.00 \%$ & $25.71 \%$ & $5.00 \%$ & 1.63 & $3.10 \%$ & 1.38 & $\mathrm{I} .46$ \\
\hline $\begin{array}{l}\text { Dhak } \\
\text { Pass>125m }\end{array}$ & $21.17 \%$ & $11.00 \%$ & $15.00 \%$ & $2.90 \%$ & 2.5 & $0.40 \%$ & 1.45 & 1.5 \\
\hline Best Way & $22.72 \%$ & $10.09 \%$ & $16.56 \%$ & $2.80 \%$ & 2.65 & $0.39 \%$ & 1.61 & 1.72 \\
\hline Pail Padhrar & $21.15 \%$ & $12.10 \%$ & $14.00 \%$ & $2.87 \%$ & 2.56 & $0.37 \%$ & $1.5 \mathrm{I}$ & 1.6 \\
\hline Limit & $\begin{array}{l}\geq 21.15 \% \text { to } \\
\leq 29.94 \%\end{array}$ & $\begin{array}{l}\geq 10.09 \% \text { to } \\
\leq 19 \%\end{array}$ & $\begin{array}{l}\geq 13.5 \% \text { to } \\
\leq 25.71 \%\end{array}$ & $\begin{array}{l}\geq 2.63 \% \text { to } \\
\leq 5.00 \%\end{array}$ & $\begin{array}{l}\geq 2.6 \text { to } \\
\leq 2.9\end{array}$ & $\begin{array}{l}\geq 0.37 \% \text { to } \\
\leq 3.1 \%\end{array}$ & $\begin{array}{l}\geq 1.38 \text { to } \\
\leq 1.61\end{array}$ & $\begin{array}{l}\geq 1.46 \text { to } \\
\leq 1.72\end{array}$ \\
\hline
\end{tabular}

Table 3 Recommendation of Sakesar limestone's based on geotechnical test

\begin{tabular}{|c|c|c|c|c|c|c|c|c|c|c|c|c|c|c|c|c|c|c|}
\hline & LA & & & AIV & & & & $A C$ & & & & ST & & & & S+ & & UV \\
\hline & SB & BC & SC & SB & BC & SC & C & SB & BC & SC & C & SB & BC & SC & C & $\mathbf{S}$ & $\mathbf{P}$ & $\mathbf{S}$ \\
\hline Tobar Valley & $\mathrm{R}$ & $\mathrm{R}$ & $\mathrm{R}$ & $\mathrm{R}$ & $\mathrm{R}$ & $\mathrm{R}$ & $\mathrm{R}$ & $\mathrm{HR}$ & $\mathrm{HR}$ & $\mathrm{R}$ & $\mathrm{R}$ & $\mathrm{R}$ & $\mathrm{R}$ & $\mathrm{R}$ & $\mathrm{R}$ & $Y$ & $Y$ & $Y$ \\
\hline Dhak Pass $<125 \mathrm{~m}$ & $\mathrm{R}$ & $\mathrm{R}$ & $\mathrm{R}$ & $\mathrm{R}$ & $\mathrm{R}$ & $\mathrm{R}$ & $\mathrm{R}$ & W & W & W & W & $\mathrm{R}$ & $\mathrm{R}$ & $\mathrm{R}$ & $\mathrm{R}$ & $\mathrm{N}$ & $\mathrm{N}$ & $Y$ \\
\hline
\end{tabular}


Table continue

\begin{tabular}{|c|c|c|c|c|c|c|c|c|c|c|c|c|c|c|c|c|c|c|}
\hline & LA & & & AIV & & & & $\mathrm{ACl}$ & & & & ST & & & & $\mathbf{S +}$ & & UV \\
\hline & SB & BC & SC & SB & BC & SC & C & SB & BC & SC & C & SB & BC & SC & C & $\mathbf{S}$ & $\mathbf{P}$ & $\mathbf{s}$ \\
\hline Dhak Pass $>125 \mathrm{~m}$ & $\mathrm{R}$ & $\mathrm{R}$ & $R$ & $R$ & $\mathrm{R}$ & $H R$ & $R$ & $R$ & $R$ & $\mathrm{R}$ & $\mathrm{R}$ & $R$ & $R$ & $R$ & $\mathrm{R}$ & $Y$ & $Y$ & Y \\
\hline Best way & $\mathrm{R}$ & $\mathrm{R}$ & $\mathrm{R}$ & $R$ & $\mathrm{R}$ & $\mathrm{HR}$ & $R$ & $R$ & $R$ & $\mathrm{R}$ & $\mathrm{R}$ & $R$ & $R$ & $R$ & $\mathrm{R}$ & $Y$ & Y & Y \\
\hline Pail Padhrar & $\mathrm{R}$ & $\mathrm{R}$ & $\mathrm{R}$ & $\mathrm{R}$ & $\mathrm{R}$ & $\mathrm{R}$ & $\mathrm{R}$ & HR & $\mathrm{HR}$ & $\mathrm{R}$ & $\mathrm{R}$ & $\mathrm{R}$ & $\mathrm{R}$ & $\mathrm{R}$ & $\mathrm{R}$ & $Y$ & $Y$ & Y \\
\hline
\end{tabular}

The Specific gravity is indicative of strength of a stone with high specific gravity values considered as strong. The recommended sp.gr value fall in the range of $\geq 2.6-\leq 2.9$, with analyzed samples having range of $\geq 1.63-2.65$ (Table 3), based on comparisons all sample are recommended to be strong except Dhak Pass (less than 125meters) (Table 3). The main reason for determining the unit weight (void content) is to establish accurate material proportions for designing concrete mixes. A minor reason is to determine mass/volume values of products for purchase agreements. The unit weight value of limestone in loose and compacted condition is from $\geq 1.38 \mathrm{KN} / \mathrm{m}^{3}$ to $\leq 1.61 \mathrm{KN} /$ $\mathrm{m}^{3}$ and $\geq 1.46 \mathrm{KN} / \mathrm{m}^{3}$ to $\leq 1.72 \mathrm{KN} / \mathrm{m}^{3}$ (Table 2 ). The value refers that the limestone are bulky and compact requiring little compaction with $\%$ value change of $5.8 \%$ for minimum and $6.8 \%$ from maximum, and classified as suitable for concrete and mix design (Table 3).

\section{Conclusion}

The conclusion has been drawn based on geotechnical samples of Sakesar Limestone to classify its feasibility as usage as Base Course, Sub Base and Surface Course. The representative samples are analyzed for hardness, durability, crushing strength and toughness by adopting designated test. The conclusion has been drawn based on results by comparing it with standard values. Based on the results it is concluded,

i. The Dhak Pass $(>125 \mathrm{~m})$ and Pail Padhrar (21.15\%-21.17\%) are having low Abrasion values and classified as the hardest aggregate, best suitable for base course

ii. The Best way cement and Dhak Pass $(>125 \mathrm{~m})$ are the toughest aggregate based on AIV having range of $10.09 \%-11.00 \%$, best suitable for sub base and surface course best suitable for rock fall and landslide prone area.

iii. The Tobar Valley and Pail Padhrar are designated as suitable for surface course of having low ACV (13.50\%-14.00\%) and ST value $(2.63 \%-2.87 \%)$ highly resistant to freeze and thaw cycle.

iv. The water absorption and specific gravity and unit weight (loose/ rodded) value of all analyzed sample are good as classified as strong not porous stone, except for Dhak pass $(<125 \mathrm{~m})$, where its value are higher.

v. The overall results obtained after laboratory testing, we came to know that except few reservations (Dhak pass $<125 \mathrm{~m}$ ) all five samples qualify the testing procedure and can be declared as good aggregate for use in the road construction as, Sub Base, Base course, Surface course.

\section{Acknowledgments}

The authors are highly indebted to Transportation Laboratory, University of Engineering and Technology Lahore, Pakistan for
Analysis of Rock samples to finalize this project. The Authors are also thankful to Bestway Cement Plant for quarrying sampling.

\section{Conflicts of interest}

The authors declare that there is no conflict of interest.

\section{Funding}

None.

\section{References}

1. Kosmatka SH, Kerkhoff B, Panarese WC. Design and control of concrete mixtures: Portland Cement Assoc. 2011

2. Munir MJ, Qazi AU, Kazmi SM, et al. A literature review on alkali silica reactivity of concrete in Pakistan. Pakistan Journal of Science. 2016;68(1):53.

3. Neville AM. Properties of concrete. Longman London; 1995;4.

4. Al-Oraimi S, Taha R, Hassan H. The effect of the mineralogy of coarse aggregate on the mechanical properties of high-strength concrete. Construction and Building materials. 2006;20(7):499-503.

5. Baker D. Hendy R. Planning for sustainable construction aggregate resources in Australia. Proceedings of QUT Research Week 2005. Queensland University of Technology. 2005;1-12.

6. Bilqees R, Sarwar MR, Haneef M. et al. Source of cement raw material for the construction of Bhasha Dam in Gilgit Diamir District, Pakistan. Journal of Himalayan Earth Science. 2015;48(1).

7. Bilqees R, Shah T. Industrial application of limestone deposits of kohat, NWFP: a research towards the sustainability of the deposits. Pakistan Journal of Scientific and Industrial Research. 2007;50(5):293-298.

8. Gondal MMI, Ahsan N. Javid A. Evaluation of Shaki Sarwar and Rajan Pur aggregates for construction in southern Punjab Province, Pakistan. Geol Bull Punjab Univ. 2008;43:101-107.

9. Gondal MMI, Ahsan N, Javid AZ. Engineering properties of potential aggregate resources from eastern and central Salt Range, Pakistan. Geological Bulletin of Punjab University. 2009;44:97-103.

10. Noor S, Younas M. Study of limestone from Nizampur area for industrial utilization. J Chem Soc Pak. 2009;31(1):1-5.

11. Shah SMI. Stratigraphy of Pakistan, $22^{\text {nd }}$ edn. Geological Survey of Pakistan Publication Directorate: Quetta Pakistan. 2009;22:381.

12. ASTM. D-75 Standard Practice for Sampling Aggregates. American Association State Highway and Transportation Officials Standard (AASHTO). 2010.

13. ASTM. C 131 Standard test method for resistance to degradation of small-size coarse aggregate by abrasion and impact in the Los Angeles machine. 2006.

14. BS. BS 812/112 Methods for Determination of Aggregate Impact Value $(A I V)$. British Standards. 1990. 
15. BS. BS $812 / 110$ Methods for Determination of Aggregate Crushing Value (ACV). British Standards. 1990.

16. ASTM. 127/07 Standard Test Method for Relative Density (Specific Gravity) and Absorption of Coarse Aggregates. American Association State Highway and Transportation Officials Standard (AASHTO). 2015

17. ASTM. C-29 Standard test method for bulk density ("unit weight") and voids in aggregate. American Association State Highway and Transportation Officials Standard (AASHTO). 2009.
18. ASTM. C 88-99a Standard Test Method for Soundness of Aggregates by using Sodium Sulphate or Magnesium Sulphate. American Association State Highway and Transportation Officials Standard (AASHTO). 2013.

19. AASHTO. American Association of State Highway and Transportation Officials. Washington, DC. 1998.

20. Guide RD. American Association of State Highway and Transportation Officials. Washington, DC. 2002. 